\title{
Autotrophic and heterotrophic metabolism of microbial planktonic communities in an oligotrophic coastal marine ecosystem: seasonal dynamics and episodic events
}

\author{
O. Bonilla-Findji ${ }^{1,2}$, J.-P. Gattuso ${ }^{1,2}$, M.-D. Pizay ${ }^{1,2}$, and M. G. Weinbauer ${ }^{1,2}$ \\ ${ }^{1}$ INSU-CNRS, Laboratoire d'Océanographie de Villefranche, UMR 7093, B.P. 28, 06234 Villefranche-sur-Mer Cedex, France \\ ${ }^{2}$ Université Pierre et Marie-Curie-Paris6, Laboratoire d'Océanographie de Villefranche, UMR 7093, 06230 \\ Villefranche-sur-mer, France
}

Received: 17 February 2010 - Published in Biogeosciences Discuss.: 22 March 2010

Revised: 1 September 2010 - Accepted: 26 September 2010 - Published: 8 November 2010

\begin{abstract}
A 18 month study was performed in the Bay of Villefranche to assess the episodic and seasonal variation of autotrophic and heterotrophic ecosystem processes. A typical spring bloom was encountered, where maximum of gross primary production (GPP) was followed by maxima of bacterial respiration (BR) and production (BP). The trophic balance (heterotrophy vs. autotrophy) of the system did not exhibit any seasonal trend although a strong intraannual variability was observed. On average, the community tended to be net heterotrophic with a GPP threshold for a balanced metabolism of $1.1 \mu \mathrm{mol} \mathrm{O} \mathrm{I}^{-1} \mathrm{~d}^{-1}$. Extended forest fires in summer 2003 and a local episodic upwelling in July 2003 likely supplied orthophosphate and nitrate into the system. These events were associated with an enhanced bacterioplankton production (up to 2.4-fold), respiration (up to 4.5-fold) and growth efficiency (up to 2.9-fold) but had no effect on GPP. A Sahara dust wet deposition event in February 2004 stimulated bacterial abundance, production and growth efficiency but not GPP. Our study suggests that short-term disturbances such as wind-driven upwelling, forest fires and Sahara dust depositions can have a significant but previously not sufficiently considered influence on phytoplanktonand bacterioplankton-mediated ecosystem functions and can modify or even mask the seasonal dynamics. The study also indicates that atmospheric deposition of nutrients and particles not only impacts phytoplankton but also bacterioplankton and could, at times, also shift systems stronger towards net heterotrophy.
\end{abstract}

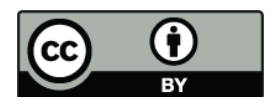

Correspondence to: M. G. Weinbauer (wein@obs-vlfr.fr)

\section{Introduction}

Bacteria take up a significant fraction of dissolved organic carbon (DOC) produced by phytoplankton and remineralize up to $50 \%$ of primary production (Azam et al., 1983). Radiolabeled substrates have been used to assess bacterial carbon production and oxygen consumption to measure respiration (Fuhrman and Azam, 1982; Kirchman et al., 1985). Measurement of bacterial respiration (BR) is difficult but pivotal, since it is needed to estimate growth efficiency, a fundamental attribute largely determining the ecological and biogeochemical role of bacteria in aquatic microbial food webs (Del Giorgio and Cole, 1998). Over the last years, a renewed interest has been put into determining BR, in order to better understand the role of bacterioplankton in the carbon fluxes (Del Giorgio and Williams, 2005).

Measurements of gross primary production (GPP) and community respiration $(R)$ have been used to assess the metabolic balance of marine ecosystems. Particularly in the late 1990s a debate took place on the predominance of heterotrophy in the most oligotrophic regions and the biogeochemical consequences of the metabolic balance in the ocean (Del Giorgio et al., 1997; Duarte and Agusti, 1998; Williams 1998). This idea seemed counter intuitive because the isolated location of those areas make them the least likely candidates for external organic inputs (Williams and Bowers, 1999). However, a series of subsequent studies have lent support to the initially surprising reports of net heterotrophy in low latitude oligotrophic areas (Serret et al., 2001; Robinson et al., 2002). Nevertheless, much of the data published to date have been derived from oceanographic transects and the number of coastal studies performed over longer time

Published by Copernicus Publications on behalf of the European Geosciences Union. 
scales remains scarce (Smith and Kemp, 2001; Duarte et al., 2004; Williams et al., 2004; Gazeau et al., 2005; Regaudiede-Gioux et al., 2009). Bacterial production and respiration play a crucial role in the GPP: $R$ balance (Del Giorgio and Williams, 2005; Sherr and Sherr, 1999).

In temperate coastal systems, a spring phytoplankton bloom is typically followed by an increase in bacterial production, e.g. as a consequence of increased dissolved primary production (Baines and Pace, 1991; Cole et al., 1988; Serret et al., 1999). Often, a phytoplankton bloom also occurs in fall (Moncoiffé et al., 2000; Alonso-Saez et al., 2008). The spring bloom is typically accompanied by an accumulation of DOC, which has been attributed to accumulation of refractory organic material (Legendre and Le Fèvre, 1995). However, this has also been explained by a "malfunctioning" of the microbial loop in the sense that the bacterial growth rate is kept low by competition between phytoplankton and bacteria for limiting nutrients and by control of bacterial biomass by predators (Thingstad et al., 1997). These two explanations are not mutually exclusive. Recent studies also suggest that atmospheric deposition could influence bacteriamediated carbon cycling stronger than previously thought (Dachs et al., 2005). For example, carbon and $P$ input by dry deposition of Sahara dust was shown to stimulate carbon mineralization in the NW Mediterranean Sea (Pulido-Villena et al., 2008; Lekunberri et al., 2010). There is also recent indication that black carbon, i.e. the incomplete combustion of fossil fuels and biomass, influences the performance of marine microbial food webs (Cattaneo et al., 2010).

Studies investigating simultaneously the tropic balance and bacterial production and community respiration are comparatively sparse for oligotrophic marine environments (Sherr and Sherr, 1999; Del Giorgio and Williams, 2005). The bay of Villefranche with its lack of a shelf and intrusion of offshore water has been considered as model of hydrological successions for the oligotrophic NW part of the Mediterranean Sea (Gostan, 1967). It has also been shown for this bay that phytoplankton community composition is affected by short-term hydrological conditions, i.e. local upwelling (Bustillos-Guzmán et al., 1995). Thus, the aim of our study was two-fold: (1) To assess the tropic balance and bacterial production and community respiration during a seasonal cycle in the oligotrophic Bay of Villefranche, and (2) to assess the potential influence of events occurring at shorter time scales on the trophic balance and bacterial parameters. The episodic events encountered during the study were upwelling, rainfall, forest fires and Sahara dust deposition.

\section{Methods}

\subsection{Study site and sample collection}

The study was conducted from November 2002 to April 2004 in the Bay of Villefranche located in the NW Mediterranean
Sea. The study site is a permanent coastal station (Point B: $43^{\circ} 51^{\prime} 10^{\prime \prime} \mathrm{N}, 07^{\circ} 19^{\prime} 00^{\prime \prime} \mathrm{E}$; bottom depth: $>90 \mathrm{~m}$ ) at the entrance of the Bay and is influenced by the Liguro-Provençal current, a cyclonic current running from east to west along the French Riviera (Nival and Corre, 1976). Under prevailing conditions this current enters the Bay, which results in continuous water renewal. There is no noteworthy shelf in this steeply descending bay. Water stratification begins typically in March, is strongest in summer and starts to erode in fall. During the onset of the stabilization of the water column in spring, a phytoplankton bloom develops; during the erosion of the stratification in fall, phytoplankton blooms have been observed as well (Bustillos-Guzmán, 1995; Claustre et al., 1989; Morel and André, 1995). The study site is considered as an oligotrophic coastal system (Sheldon et al., 1992). Samples were collected every month before sunrise in 0.5 , 10,20 and $30 \mathrm{~m}$ depth with a 201 Niskin bottle. Additional sampling was carried out during phytoplankton blooms or after specific events such as heavy rain, forest fires or Sahara dust deposition. For these additional samples GPP, net community production (NCP) and $R$ (see below) were not measured. Temperature and salinity data were obtained using a Seabird SBE25 CTD at the time of sampling.

Temperature and salinity data from Point B were also obtained from the weekly sampling program down to $75 \mathrm{~m}$ water depth (SOMLIT). SOMLIT also provided weekly data on inorganic nutrients and chlorophyll- $a(\mathrm{Chl}-a)$. Daily data on wind direction, wind speed and rain frequencies were obtained from the meteorological station at Cap-Ferrat, close to Point B (distance, ca. $1 \mathrm{~km}$ ). Daily data on irradiance (UV + PAR) were obtained from the airport Nice (distance from Point B, ca. $5 \mathrm{~km}$ ). Data on forest fires were obtained for the Var Department, which stretches to the West from the study site, i.e. in the main wind direction (Prométhée, French Mediterranean forest fire data base: http://www.promethee. $\mathrm{com} /$ prom/home.do).

\subsection{Nutrients, dissolved organic carbon, particles and Chl-a}

Total organic carbon (TOC) rather than dissolved organic carbon (DOC) was measured in order to avoid contamination during filtration. Due to the low concentration of particulate organic carbon at Point B (typically less than $10 \%$ of TOC; Weinbauer, unpublished data), it is referred to in the following as DOC. DOC was determined by high temperature oxidation with a Shimadzu 5000A TOC Analyzer (Benner and Strom, 1993). Concentrations of Chl- $a$ were measured fluorometrically, while nitrate (NO3) and phosphate (PO4) concentrations were determined using an Alliance-Instrument EV2 Autoanalyzer following standard methods (Lorenzen, 1966; Strickland and Parsons, 1972).

The concentration of particles in the water column was determined using a Coulter Counter Multisizer II within $2 \mathrm{~h}$ of sampling to avoid aggregation and denaturation of organic 
matter (Sheldon and Parsons, 1967). Counts were performed on triplicate sub-samples, ensuring that at least $10^{4}$ particles were counted.

\subsection{Bacterial abundance}

Samples $(2 \mathrm{ml})$ were fixed in glutaraldehyde $(0.5 \%$ final concentration), kept in the dark for $30 \mathrm{~min}$ at $4{ }^{\circ} \mathrm{C}$, flash frozen in liquid nitrogen and stored at $-80^{\circ} \mathrm{C}$ pending analysis. The abundance of heterotrophic bacteria was determined by flow cytometry (Becton Dickinson, FACSCalibur) upon staining with SYBRGreen I (Molecular Probes) as described previously (Gasol and Del Giorgio, 2000). Fluorescent $1 \mu \mathrm{m}$ latex beads $\left(10^{5}\right.$ beads $\left.\mathrm{ml}^{-1}\right)$ were systematically added to the bacterial samples as an internal quality standard (Polyscience Inc., Europe). Although archaea are detectable by PCR in the Bay of Villefranche, their abundance is below the detection limit using single-cell analysis (unpublished data). Therefore, in accordance with other coastal studies (Zhang et al., 2007) the community is considered bacterial in the following.

\subsection{Bacterial and planktonic community metabolism}

Water samples for community metabolism were carefully distributed into calibrated $60 \mathrm{ml}$ borosilicate bottles. Five replicates were fixed immediately and used to determine the initial oxygen concentration at $\mathrm{T} 0$ and 10 others were used to estimate the rates of dark community respiration $(R$, "dark" bottles) and net production (NCP, "light" bottles), respectively. At sunrise, the bottles were suspended in situ at the depths of sampling using a rope tethered to a permanent buoy. Incubations lasted $24 \mathrm{~h}$. Additional water was transferred directly from the Niskin bottle into 101 acidwashed carboys and transported immediately to the laboratory $(<15 \mathrm{~min})$. Subsamples were taken for measurements of BR and rates were determined in the laboratory, following the same procedures as for the estimation of $R$, after prefiltration of the water through a $0.8 \mu \mathrm{m}$ pore size polycarbonate filter (diameter $142 \mathrm{~mm}$, Millipore). Incubations were carried out in the dark at in situ temperature $\left( \pm 1^{\circ} \mathrm{C}\right)$ for 24 and $48 \mathrm{~h}$. Dissolved oxygen was fixed immediately at the beginning and end of the incubation and measured by the Winkler technique using a potentiometric end-point detector (Anderson et al., 1992) with an Orion redox electrode (9778SC) and a custom built titrator. Reagents and standardizations were otherwise similar to those described by Knap et al. (1996). Community and bacterial respiration (BR) as well as net community production (NCP) were calculated from changes in oxygen concentration after incubation in the "dark" and "light" bottles, respectively, relative to their concentration at T0. Respiration rates $\left(\left[\mathrm{O}_{2}\right] \mathrm{T} 0\right.$ - $\left[\mathrm{O}_{2}\right]$ dark bottle), NCP $\left(\left[\mathrm{O}_{2}\right]\right.$ light bottle $\left.-\left[\mathrm{O}_{2}\right] \mathrm{T} 0\right)$, and gross primary production $(\mathrm{GPP}=\mathrm{NCP}+R)$ were expressed in $\mu \mathrm{mol} \mathrm{O} 2 \mathrm{l}^{-1} \mathrm{~d}^{-1}$. Changes in the trophic conditions were characterized by the GPP/ $R$ ratio, where GPP/R $>1$ represents net autotrophy, GPP $R=1$ represents metabolic balance and GPP/ $R<1$ represents net heterotrophy.

$\mathrm{BP}$ was measured using the ${ }^{3} \mathrm{H}$-leucine incorporation method described by Smith and Azam (1992). Four replicates from each depth were spiked with $12 \mathrm{nM}$ of ${ }^{3} \mathrm{H}$-leucine and either 0,40 or $80 \mathrm{nM}$ of "cold" leucine, in order to check for saturation conditions, and incubated in the dark at in situ temperature for $1 \mathrm{~h}$. We used the conversion factor of $1.545 \mathrm{~kg} \mathrm{C} \mathrm{mol} \mathrm{Leu}^{-1}$ (Kirchman and Ducklow 1993) and assumed a carbon content of $20 \mathrm{fg} \mathrm{C} \mathrm{cell}^{-1}$ (Lee and Fuhrman, 1987). Bacterial growth efficiency was calculated as $\mathrm{BGE}=\mathrm{BP} /(\mathrm{BP}+\mathrm{BR})$, assuming a respiratory quotient of 1. Bacterial carbon demand (BCD) was calculated as $\mathrm{BP}+\mathrm{BR}$.

\subsection{Statistics}

Spearman correlation coefficients $(\rho)$ were calculated to test the relationship between parameters. GPP and $R$ relationships were analysed using the reduced major axis (r.m.a.) regression model. Mann-Whitney U-tests were used to to assess differences between the forest fire period and the period right before and afterwards (significance level, $P<0.05$ ). Differences of parameters between hydrologically defined periods were assessed by non-parametric analysis of variance. In case these Kruskal-Wallis tests were significant (significance level, $P<0.05$ ), Mann-Whitney U-tests were performed between data of pairs of hydrologically defined periods (significance level, $P<0.05$ ).

\section{Results}

\subsection{Environmental conditions}

The increase of atmospheric irradiance with time was faster in spring 2003 than in spring 2004 (Fig. 1a). The water temperature was homogenous with depth from December 2002 to February 2003 and from December 2003 to February 2004 (Fig. 2a). Between these two periods and in October to November 2002, the water column was thermally stratified. The strong correlation between temperature and sigma-t $(\rho)=0.982$; data not shown) support previous findings that density is mostly driven by temperature in the Bay of Villefranche (Bustillos-Guzmán et al., 1995). Based on a stratification index three types of periods differing with respect to water column stability were identified (as also shown previously for this bay; Bustillos-Guzmán et al., 1995): (1) a summer stratified periods, (2) mixed periods and (3) semimixed periods (for spring and fall-winter conditions) (Fig. 3). The fall-winter semi-mixed periods were very short.

Superimposed on these periods, several episodic events were observed during the study period. A local episodic upwelling event occurred in the first week of July during stratification period as indicated by a temperature drop from 

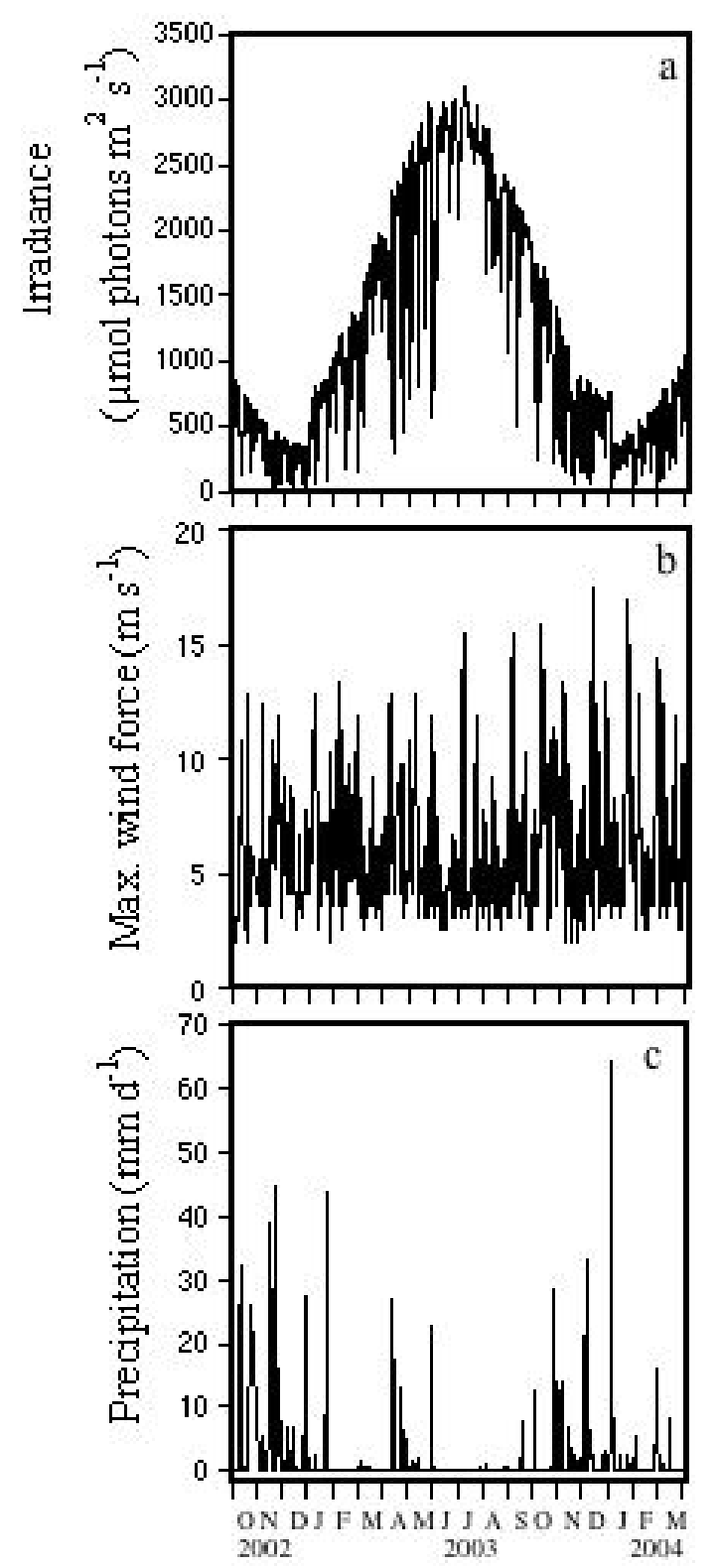

Fig. 1. Meteorological parameters during the study period. Data were collected on a daily basis. (a) Irradiance, (b) wind intensity and (c) precipitation.

$25.9^{\circ} \mathrm{C}$ to $18.7^{\circ} \mathrm{C}$ and a mixing of the top ca. $30 \mathrm{~m}$ layer (Fig. 2a). This upwelling was likely caused by strong winds with daily maximum wind speed of $11-16 \mathrm{~m} \mathrm{~s}^{-1}$ between 2 July and 4 July (Fig. 1b), since wind speeds above $10 \mathrm{~m} \mathrm{~s}^{-1}$ can cause a change in the water circulation in the Bay and cause upwelling and intrusion of colder and nutrient-rich deep water into the Bay (Nival, 1975; Nival and Corre, 1976).

The highest monthly rain frequencies were observed in spring (April-May 2003, ca. 11 days corresponding to a total of $105 \mathrm{~mm}$ ) and autumn (October 2003, 11 days and a
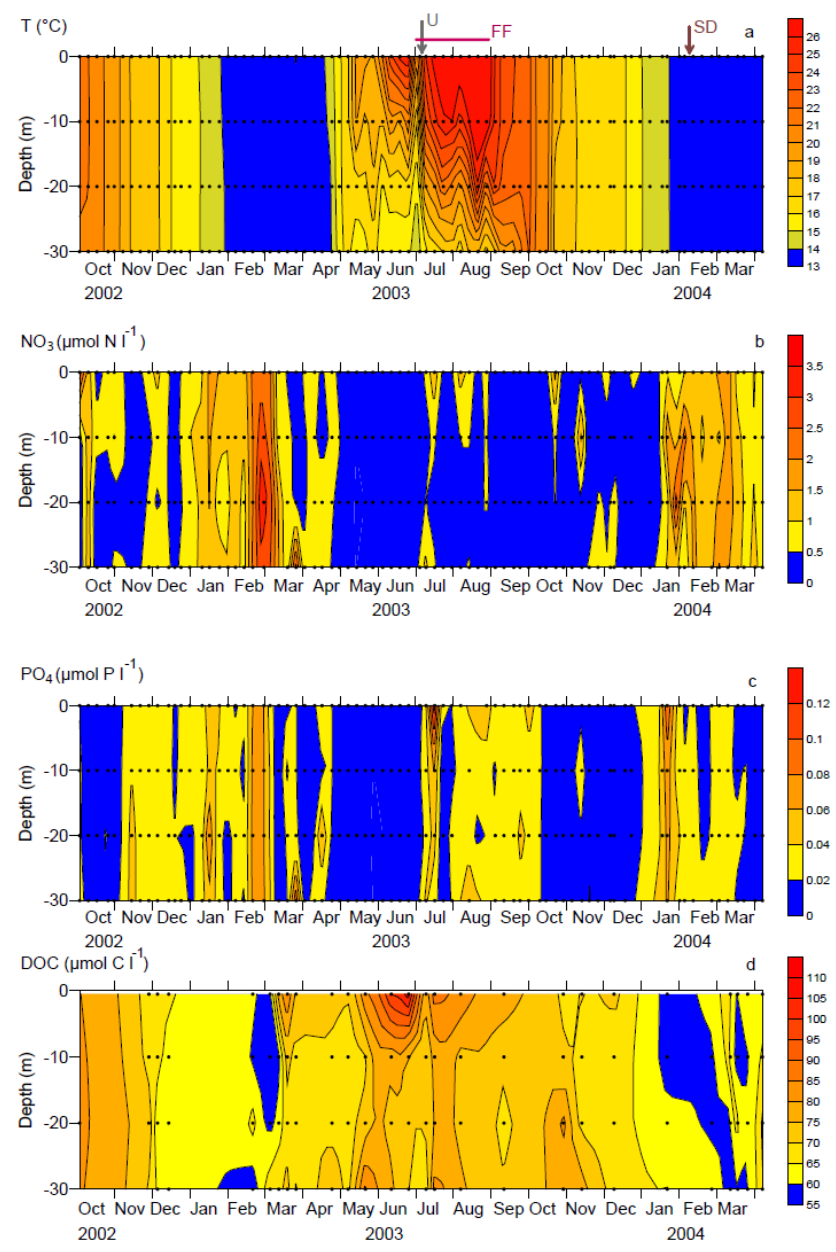

Fig. 2. Physical and chemical characteristics during the study period for the upper $30 \mathrm{~m}$ of the water column. Data (except for DOC) were typically collected on a weekly basis. The dots represent sampling dates. (a) Temperature $(T)$, (b) nitrate $\left(\mathrm{NO}_{3}\right)$, (c) phosphate $\left(\mathrm{PO}_{4}\right)$ and d) dissolved organic carbon (DOC). SD, Sahara dust deposition event, FF, forest fire period; U, upwelling event.

total of $83 \mathrm{~mm}$; December 2003, 12 days and a total of $114 \mathrm{~mm}$ ). Daily precipitation is shown in Fig. 1c. In February 2004 a strong Sahara dust wet deposition event occurred, which was associated with a cold front and even reached central Europe (EUMETSAT data base; http://www.eumetsat. int/Home/index.htm). Rain occurred between 20 February and 24 February with a daily precipitation ranging from 2.0 to $15.8 \mathrm{~mm}$; total precipitation during these four days was $29 \mathrm{~mm}$.

Compared to 2002 and 2004, the summer period of 2003 (July-August) was characterized by a higher frequency of forest fires in the west of the sampling area (Fig. 4). The main wind direction during the forest fire period was westerly and the deposition of fly ash into the Bay of Villefranche could be observed on one occasion. The number of forest fires was 25 to $50 \%$ higher in 2003 than in 2002 or 2004 


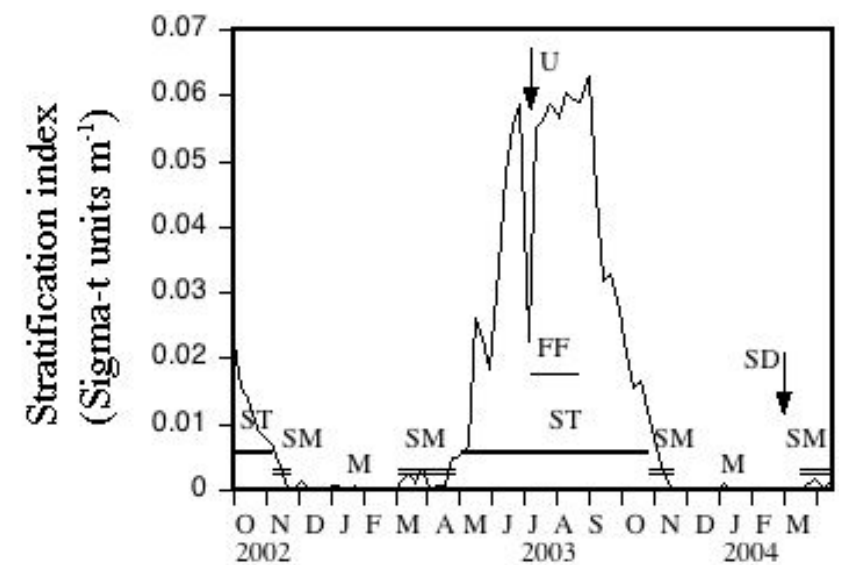

Fig. 3. Hydrological conditions and episodic events during the study period. Stratification index was calculated at the average density difference $\mathrm{m}^{-1}$ of the 0-75 $\mathrm{m}$ layer (Bustillos-Gyzmán et al., 1995). ST, summer stratification period (single line); M, mixed period; SM, semi-mixed conditions (double line), spring and fallwinter conditions; SD, Sahara dust deposition event, FF, forest fire period; U, upwelling event.

(Fig. 4). Moreover, the forest fires destroyed 20 to 100 times more forest area and large fires $\left(>1 \mathrm{~km}^{2}\right.$ destruction) were $\geq 7$ times more frequent in 2003 than in 2002 and 2004 .

\subsection{Nutrients, DOC and concentration of particles}

Nitrate and phosphate concentrations ranged from undetectable levels to $3.75 \mu \mathrm{M}$ and $0.14 \mu \mathrm{M}$, respectively (Fig. 2b, c). The highest values occurred in winter and dropped during the spring phytoplankton bloom. Nitrate concentrations were significantly lower during the stratification than during the semi-mixed and mixed period (Mann-Whitney, $P<0.05$ ). Phosphate concentrations showed the same trend, however, differences between periods were not significant (KruskallWallis, $P>0.05$ ). In summer, phosphate concentrations were relatively high in the entire water column following a local upwelling event and the forest fire period (JulyAugust); the maximum value $(0.14 \mu \mathrm{M})$ was measured in July in surface water. Phosphate and nitrate values were ca. $1.4-4$ fold higher in July-August $(0.052$ and $0.72 \mu \mathrm{M}$, respectively) than in June ( $\leq 0.001$ and $0.16 \mu \mathrm{M}$, respectively) and September ( 0.025 and $0.26 \mu \mathrm{M}$, respectively) (Fig. 5). These differences were significant for both June and September (t-test, $P<0.05$ ). In February 2004, sampling was performed 3 days after a strong Sahara dust deposition event associated with heavy rains. Nitrate and phosphate concentrations were elevated after the Sahara dust wet deposition event compared to the week before (Fig. 2b, c).

DOC concentrations ranged from 56 to $108 \mu \mathrm{m}$ (Fig. 2d). Following the low concentrations detected during winter 2002-2003, DOC increased from the spring bloom until the end of June when the highest value was measured in surface

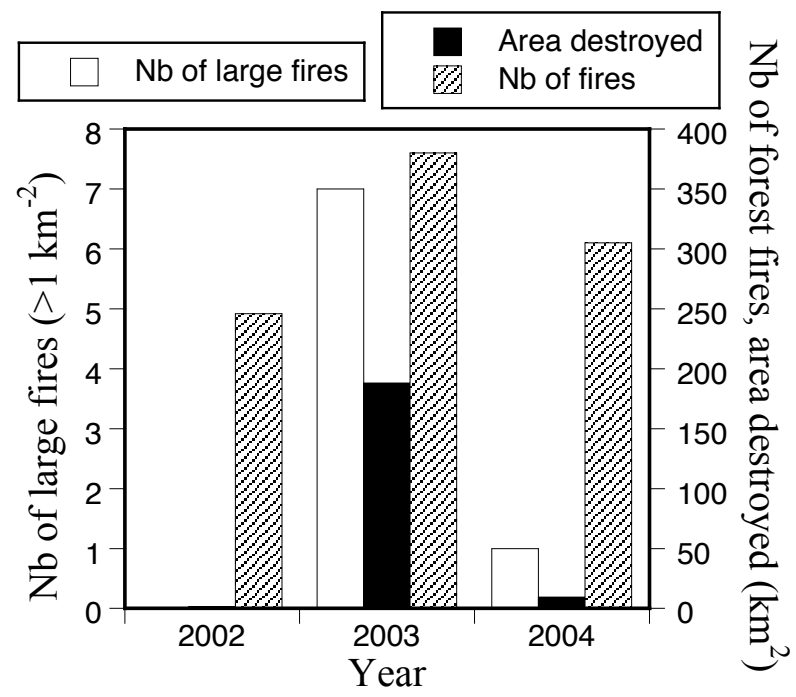

Fig. 4. Frequency of forest fires in the Var Department. The Var Department is in the West of the study site. In summer mainly westerly winds occur. Forest fires occurred almost exclusively during July and August.

water. Afterwards, from summer 2003 to February 2004, DOC decreased throughout the water column and increased again during the phytoplankton bloom 2004 (for bloom conditions see below). DOC concentrations were significantly higher during the stratified than during the semi-mixed and mixed period (Mann-Whitney, $P<0.05$ ).

Particle concentrations showed the lowest values in autumn (811 particles $\mathrm{ml}^{-1}$ ) at 20 and $30 \mathrm{~m}$ depth (data not shown). The highest values were measured throughout the water column during the phytoplankton bloom of 2003 (4090 particles $\mathrm{ml}^{-1}$ ) and in February 2004 at $20 \mathrm{~m}$. Particle concentration averaged over depth was almost 2-fold higher in after the dust event than in January (Fig. 6a). Particle concentrations were significantly higher during the semi-stratified than during the stratified and mixed period (Mann-Whitney, $P<0.05)$.

\subsection{Phytoplankton and metabolic parameters}

Chl- $a$ concentrations ranged from 0.04 to $0.80 \mu \mathrm{g} \mathrm{l}^{-1}$ (Fig. 7a). The maximum concentration was measured between $10 \mathrm{~m}$ and $20 \mathrm{~m}$ depth in early spring 2003 marking the phytoplankton bloom and a second peak was observed in fall 2003 , with values up to $0.36 \mu \mathrm{g} 1^{-1}$ in the surface. In 2004, Chl- $a$ concentrations were as high as $0.59 \mu \mathrm{gl}^{-1}$ in March. The spring bloom started with diatoms and was followed by autotrophic flagellates; after the proper bloom a period occurred with maximum abundances of Synechococcus (data not shown). Chl- $a$ concentrations were significantly higher during the semi-stratified than during the stratified and mixed period (Mann-Whitney, $P<0.05$ ). 


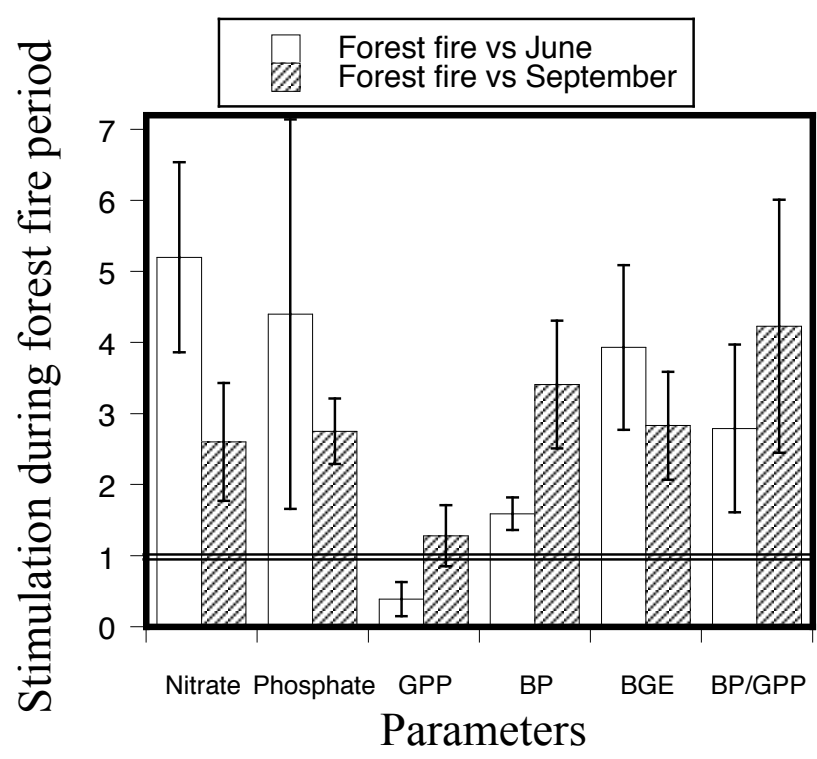

Fig. 5. Stimulation of nutrients and biological parameters during the forest fire period (July-August 2003). Simulation was calculated as ratio of values from the forest fire period vs the period before (June) or afterwards (September). The double line indicates zero stimulation. Standard errors were calculated from the 3-7 depth-averaged values obtained during the forest fire period and are shown as error bars. Nitrate and phosphate data from the upwelling event early July 2003 were excluded. Mann-Whitney test statistics showed that nitrate and phosphate concentrations were significantly higher in July-August than in June and September $(P<0.05)$. For the other parameters, not enough data points were available for performing statistical tests. GPP, gross primary production; BP, bacterial production; BGE, bacterial growth efficiency.

GPP values ranged from $<0.01$ to $5.85 \mu \mathrm{mol} \mathrm{O}_{2} \mathrm{l}^{-1} \mathrm{~d}^{-1}$ and was up to 3 -fold higher in surface water than at the other depths, particularly in March and June 2003 when the highest rates were measured (Fig. 7b). The lowest GPP occurred in January and February 2004 at $30 \mathrm{~m}\left(<0.02 \mu \mathrm{mol} \mathrm{O}_{2} \mathrm{l}^{-1} \mathrm{~d}^{-1}\right)$ but values were typically also low in summer and in autumn 2003. The average value of GPP in July-August $\left(1.2 \mu \mathrm{mol} \mathrm{O}_{2} \mathrm{l}^{-1} \mathrm{~d}^{-1}\right)$ was similar to the September value $\left(0.96 \mu \mathrm{mol} \mathrm{O} \mathrm{l}^{-1} \mathrm{~d}^{-1}\right)$ but somewhat (ca. 60\%) lower than in June $\left(2.0 \mu \mathrm{mol} \mathrm{O}_{2} \mathrm{l}^{-1} \mathrm{~d}^{-1}\right)$ (Fig. 5). GPP rates were significantly higher during the semi-stratified than during the mixed period (Mann-Whitney, $P<0.05$ ). Thus, Chl- $a$ and GPP data indicate that phytoplankton blooms were associated with the semi-mixed layer.

NCP ranged from -5.74 to $7.58 \mu \mathrm{mol} \mathrm{O}_{2} \mathrm{l}^{-1} \mathrm{~d}^{-1}$ and followed the same temporal trends in all depths with a slightly higher variability in the surface (Fig. 7c). Positive values were measured in the winter 2002 and early spring 2003 but rates were close to zero or negative throughout the summer and the rest of the study period. $R$ ranged from 0.07 to $7.88 \mu \mathrm{mol} \mathrm{O} \mathrm{I}^{-1} \mathrm{~d}^{-1}$, and was generally lower at $20-30 \mathrm{~m}$ than near the surface, particularly from June to October.
The highest $R$ occurred in early spring 2004 when it exceeded up to 7 times that measured during the same period in 2003 (Fig. 7d). The $R$ values in July and August (average, $1.25 \mu \mathrm{mol} \mathrm{O} \mathrm{O}^{-1} \mathrm{~d}^{-1}$ ) was lower than in in June (average, $2.45 \mu \mathrm{mol} \mathrm{O}_{2} \mathrm{l}^{-1} \mathrm{~d}^{-1}$ ) but similar to the September values (average, $1.14 \mu \mathrm{mol} \mathrm{O} \mathrm{I}^{-1} \mathrm{~d}^{-1}$ ). NCP and $R$ values did not differ significantly between the three hydrologically defined periods (Kruskal-Wallis, $P>0.05$ ).

GPP and $R$ ranged from 10 to 183 and from 29 to $181 \mu \mathrm{mol} \mathrm{O} \mathrm{m}^{2} \mathrm{~d}^{-1}$, respectively (Fig. 8a). Depth averaged GPP was up to ca. 3-fold higher than depth averaged $R$ during winter 2002 and spring 2003 (Fig. 8a), resulting in a net autotrophic balance, whereas from May 2003 to April 2004, $R$ was about twice higher than GPP. Thus, metabolic balance in Villefranche Bay was net heterotrophic most of the studied period but a pronounced temporal variability was observed. The GPP: $R$ volumetric ratio averaged from October 2002 to September 2003 was 1.2 and was about of 0.6 averaged from May 2003 to April 2004. GPP: $R$ was higher in the semimixed than in the other periods, however, this difference was not significant (Kruskall-Wallis, $P>0.05$ ). There was a positive relation between the GPP: $R$ ratio and GPP as illustrated by the reduced major axis (r.m.a) regression model which explained $56 \%$ of the variance in the ratio (Fig. 8b). The threshold GPP to reach a balanced metabolism in Villefranche Bay was estimated at $1.1 \mu \mathrm{mol} \mathrm{O}_{2} \mathrm{l}^{-1} \mathrm{~d}^{-1}$.

\subsection{Bacterial parameters}

Bacterial abundance ranged from $4.4 \times 10^{5}$ to $12 \times$ $10^{5}$ cells ml $^{-1}$ across the sampling period (Fig. 9a). Overall, the lowest abundance occurred in September-October 20022003 and December 2003-February 2004, whereas highest values were measured during the spring phytoplankton bloom (Fig. 9a). Also, bacterial abundances were significantly higher during the semi-stratified than during the stratified and mixed period (Mann-Whitney, $P<0.05$ ). After the dust event in February 2004, bacterial abundance showed a temporary peak and was on average $57 \%$ higher than in the previous months (Fig. 6b).

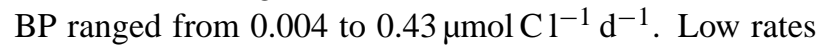
were measured in autumn and winter, i.e. during the the mixing period, whereas the highest activity occurred after the spring phytoplankton bloom and in early summer (Fig. 9b). Additionally, BP peaked in May (following the Synechococcus bloom) and July 2003 (following a local upwelling). Overall, BP rates were significantly higher during the stratified and semi-stratified than during the mixed period (MannWhitney, $P<0.05$ ). In July-August, the BP was on average ca. $60 \%$ higher than in June and 2.4 fold higher than in September (Fig. 5). On 25 February, Sahara dust had reached $30 \mathrm{~m}$ as indicated by the particle profile. At this depth, the $\mathrm{BP}$ value was 2.1 to 2.3 fold higher than in shallower water (Fig. 6d). The depth-integrated value of BP at this sampling date was 2.9 fold higher than at 20 January, 2004 and 2.7 fold 


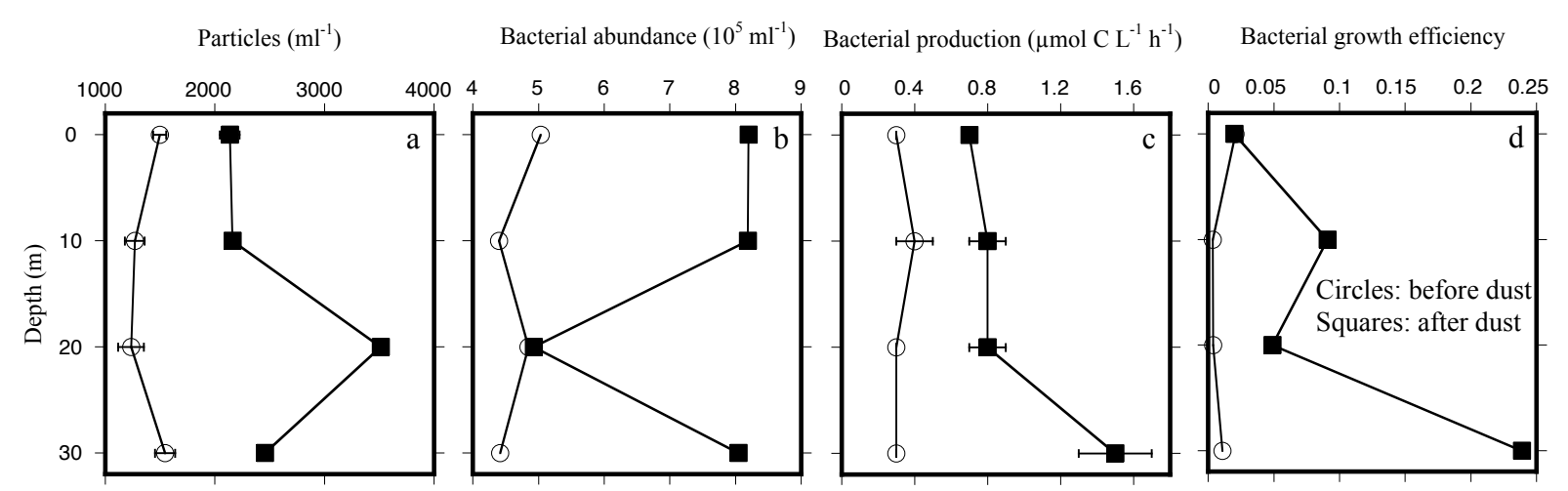

Fig. 6. Comparison of data collected several days after the Sahara dust event (20-21 February, 2004) with data collected the month before. (a) particles, (b) bacterial abundance, (c) production and (d) growth efficiency.

higher than on 19 February, 2003. Across the study period, BP represented between ca. $1 \%$ and $70 \%$ of GPP (assuming a photosynthetic quotient of 1), and reached the highest values during the spring blooms of 2003 (up to 37\%) and 2004 (up to $70 \%)$. Specific BP $\left(\mathrm{BP}\right.$ cell $^{-1}$ ) varied in the same way as BP (data not shown).

BR ranged from 0.03 to $3.1 \mu \mathrm{mol} \mathrm{O}_{2} \mathrm{l}^{-1} \mathrm{~d}^{-1}$ and was lower than $0.047 \mu \mathrm{mol} \mathrm{O}_{2} \mathrm{I}^{-1} \mathrm{~d}^{-1}$ between 10 and $30 \mathrm{~m}$ during winter 2002. It increased starting from the spring 2003 phytoplankton bloom (Fig. 9c). BR rates did not differ significantly between the three hydrologically defined periods (Kruskal-Wallis, $P>0.05$ ). The highest values occurred in association with a local upwelling event and in August 2003. However, the June and July-August values were similar, whereas in July-August values were 3.8 to 4.5 fold higher than in September. BR was low at all depths in autumn but increased again in winter 2003 when it reached the highest rates between 10 and $20 \mathrm{~m}$. No consistent effects were found following the Sahara dust deposition event.

BGE ranged from 0.005 to 0.64 , was high during the phytoplankton bloom and peaked in March at all depths (0.45 to 0.50 ; Fig. 9 d). BGE did not differ significantly between the three hydrologically defined periods (KruskalWallis, $P>0.05$ ). In July-August BGE was 2.9 fold higher than in June and 1.8 fold higher than in September (Fig. 5). After the Sahara dust event, BGE ranged from 0.02-0.24 (average: 0.10 ) across the water column with the highest value in $30 \mathrm{~m}$, whereas before the event, BGE ranged from 0.004 to 0.02 (Fig. 6d). BCD ranged from 0.04 to $3.2 \mu \mathrm{mol} \mathrm{Cl}^{-1} \mathrm{~d}^{-1}$. Its distribution over time and depth was similar to that of BP (data not shown). BCD was high at the beginning of the summer, and low in autumn and winter (data not shown). $\mathrm{BCD}$ values were significantly higher during the stratified than during the mixed period (Mann-Whitney, $P<0.05$ ). The strongest changes in BGE and in BCD occurred from March to early June 2003.

\subsection{Co-variation between parameters}

Many significant co-variations between parameters were found. In Table 1, only those co-variations were considered with Spearman correlation coefficients $(\rho)$ larger than 0.5 (which were all statistically significant at $P<0.0001$ ). For example, BR decreased and BP increased with BGE, whereas BCD increased with BR and specific BP. Positive correlations were found between Chl- $a$ concentration and the parameters particle concentration and bacterial abundance. A positive correlation was also found between phosphate and nitrate. DOC increased with increasing temperature.

For GPP, NCP and $R$ sampling frequency was lower. For most parameters, the relationship was either not significant or significant at a low level $(P<0.05$; BP positively correlated with GPP and $R)$. Highly significant correlations $(P<$ $0.0001)$ were found between with $R$ and GPP $(\rho=0.534)$ and between $R$ and NCP $(\rho=-0.621)$.

\section{Discussion}

\subsection{Evaluation of methods}

It is well known that the used approaches to assess GPP, $R$, $\mathrm{BP}$ and BR have inherent problems in the sense of measuring rates precisely. Therefore, the values of data such as GPP: $R, \mathrm{BCD}$ and BGE presented in this (and other) studies should be considered with caution. However, less problems should be expected, when data are used in a comparative way as in this study. In addition, GPP estimations based on the $\mathrm{O}_{2}$ dark-light technique were not significantly different from ${ }^{18} \mathrm{O}$-labelling based estimates carried out in parallel in the Bay of Villefranche (Gonzalez et al., 2008).

\subsection{Trophic balance and planktonic metabolism}

Large differences in the metabolic balance were observed with an initial autotrophic period in winter 2002 and spring 

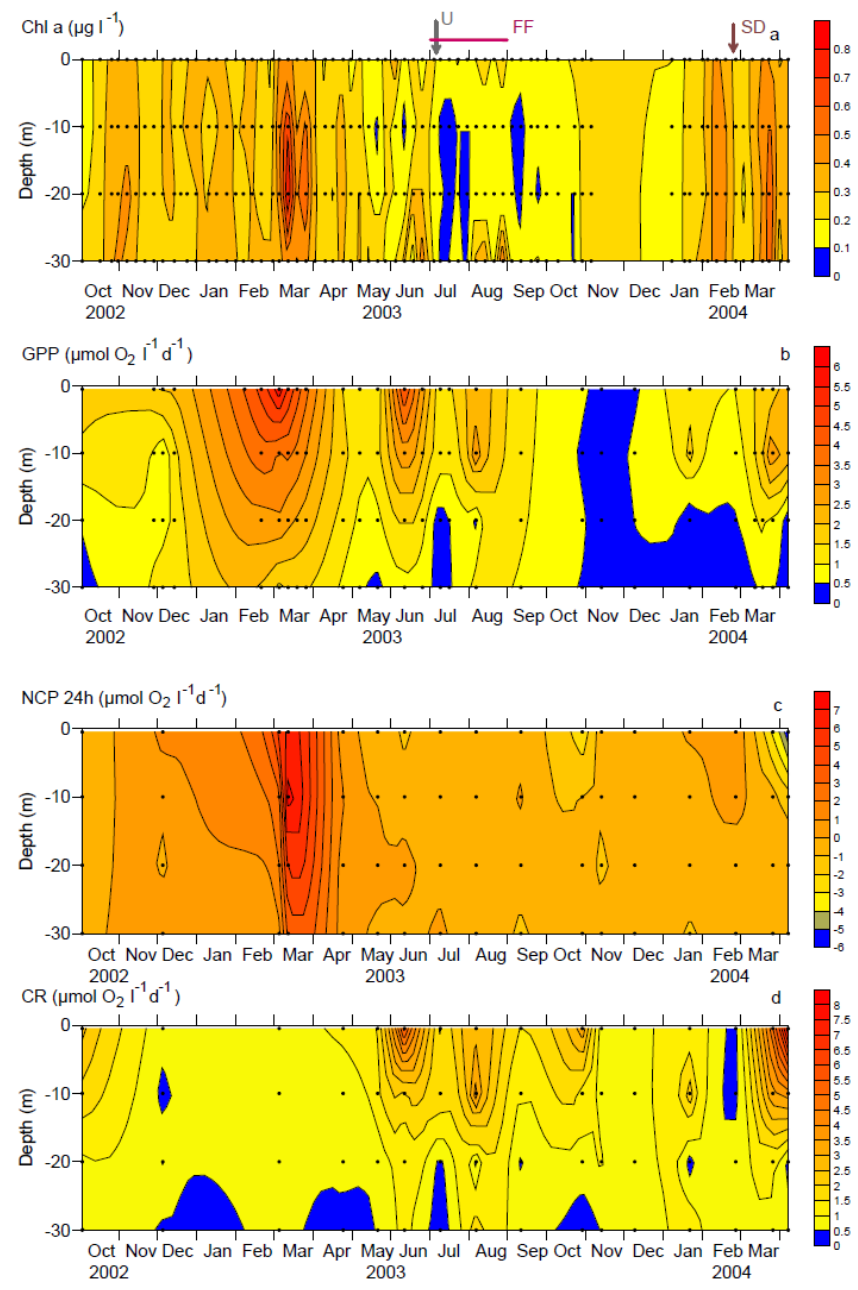

Fig. 7. Changes in phytoplankton and community parameters during the study period for the upper $30 \mathrm{~m}$ of the water column. Chl- $a$ data were collected on a weekly basis. The dots represent sampling dates. (a) Chl- $a$, (b) gross primary production (GPP), (c) net community production (NCP) and (d) community respiration $(R) . \mathrm{SD}$, Sahara dust deposition event, FF, forest fire period; U, upwelling event.

2003 followed by a shift towards equilibrium in summer and net heterotrophy from fall 2003 until April 2004. This switch between autotrophy and heterotrophy, which has also been observed in other coastal regions and in the NW Mediterranean (Navarro et al., 2004), did not follow a seasonal pattern. Indeed, the maximum GPP rate was higher in 2003 than in 2004, whereas $R$ exhibited an opposite trend. During the autotrophic period GPP and $R$ rates were temporarily uncoupled with $R$ remaining relatively stable compared to the strong increases observed in GPP thus, suggesting that changes in primary production were mainly driving the GPP: $R$ ratio. The trend towards heterotrophy during most of the study period is consistent with other studies of NW Mediterranean coastal
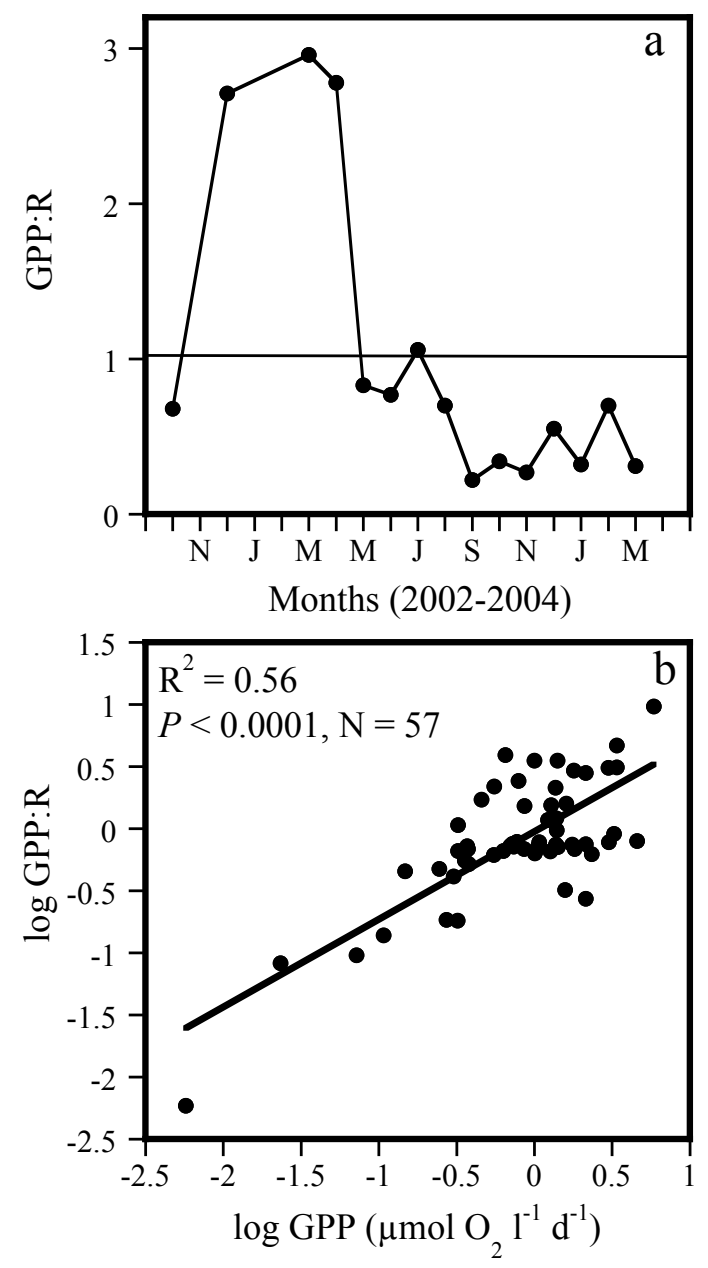

Fig. 8. Trophic balance and planktonic metabolism. (a), GPP: $R$ and (b) relationship between GPP and GPP: $R$. Data in (a) are calculated from depth-averaged values. The parameters for the regression line in (b) are $\mathrm{y}=-0.051+0.677 \mathrm{x}$ for $\log$ transformed data using the reduced major axis (r.m.a.) regression model.

sites (Duarte et al., 2004; Navarro et al., 2004; Satta et al., 1996). The GPP threshold for a balanced metabolism (GPP: $R=1$ ) calculated from the regression in Fig. 8 was $1.1 \mu \mathrm{mol} \mathrm{O}_{2} \mathrm{l}^{-1} \mathrm{~d}^{-1}$. This value was identical with the value for the global ocean $\left(1.1 \mu \mathrm{mol} \mathrm{O} \mathrm{l}^{-1} \mathrm{~d}^{-1}\right)$ (Duarte and Regaudie-de-Gioux, 2009) but lower compared to other values for the Mediterranean Sea such for Palma Bay (Balearic Islands, $2.8 \mu_{\mathrm{mol} \mathrm{O}}^{-1} \mathrm{~d}^{-1}$ ) over an annual cycle (Navarro et al., 2004), Blanes Bay (Spain, $3.95 \mu \mathrm{mol} \mathrm{O} \mathrm{l}^{-1} \mathrm{~d}^{-1}$ ) from a 6 years study period (Duarte et al., 2004) or from several cruises into offshore waters of the Western Mediterranean Sea $\left(3.5 \mu \mathrm{mol} \mathrm{O}_{2} \mathrm{l}^{-1} \mathrm{~d}^{-1}\right)$ (Regaudie-de-Gioux et al., 2009). The published data from the Mediterranean Sea imply that the GPP necessary to balance community respiration is three times higher than that for the global ocean. This would suggests that in the Mediterranean Sea a higher GPP is required 

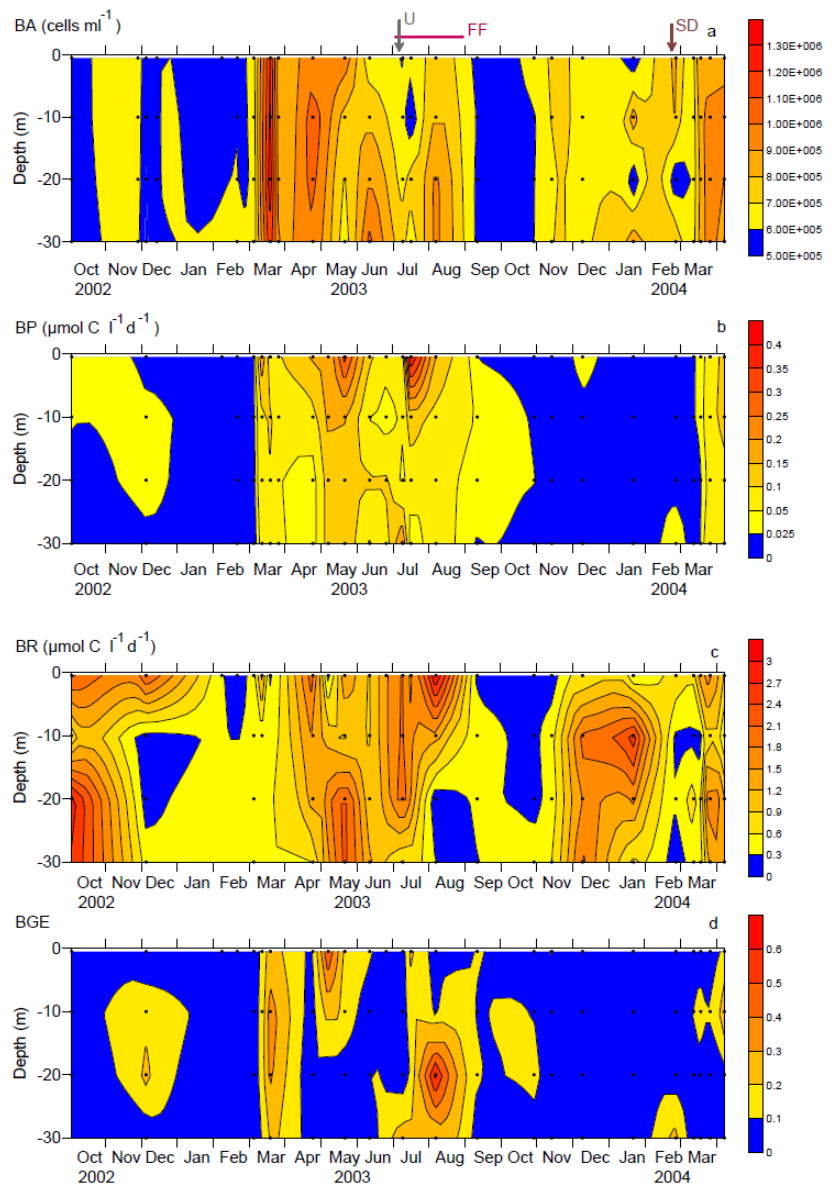

Fig. 9. Changes in bacterial parameters during the study period for the upper $30 \mathrm{~m}$ of the water column. The dots represent the sampling dates. (a) Bacterial abundance (BA), (b) production (BP), (c) respiration (BR) and (d) growth efficiency (BGE). SD, Sahara dust deposition event, FF, forest fire period; U, upwelling event.

to compensate for the excess respiration supported by the high inputs of allochthonous organic carbon (Regaudie-deGioux et al., 2009). Our data suggest that environments or situations exist in the Mediterranean Sea where such a higher GGP is not required.

Heterotrophy indicates that the planktonic community relied on sources other than planktonic primary production to sustain the organic carbon demand. Macrophyte beds can play an important role as source of DOC to sustain excess respiration (Duarte and Cebrian, 1996; Duarte et al., 2005). Gradients between shallow-autotrophic and deepheterotrophic areas were observed in the Bay of Palma (Gazeau et al., 2005). Although the Bay of Villefranche also harbours extensive beds of the seagrass Posidonia oceanica, there is no seagrass bed at the Point B sampling station. In addition, the drop-off is much steeper than in the aforementioned bays and there is basically no shelf. Thus, while we cannot fully exclude the possibility that seagrass beds are a source of DOC sustaining the heterotrophic status of the bay, this influence should be relatively small.

The lack of seasonality and the low the GPP: $R$ ratio from August-December 2003 and in 2004 is more puzzling. It is possible that the phytoplankton bloom was short-lived. However, metabolic parameters were measured on a weekly basis in March 2004 until the end of the study period (6 April) during the onset of the spring bloom. Thus, it is unlikely that a low sampling frequency caused the observed heterotrophy. Another possible cause of the changes between the autotrophic and heterotrophic period could also be related to changes in the relative contribution of the different phytoplankton size classes to the total GPP rate (Smith and Kemp, 2001); however, no data is available to evaluate this hypothesis. The heterotrophic part of the study period was also characterized by high nutrient concentrations in the bay probably due to episodic events such as upwelling and forest fires (see below). This could have influenced the trophic balance. It has been shown before that upwelling events can strongly influence the trophic balance (Moncoiffé et al., 2000). Nevertheless, it has to be pointed out that most studies report on a heterotrophic balance in the Mediterranean Sea (Duarte et al., 2004; Navarro et al., 2004; Regaudie-de-Gioux, 2009). Thus, our study supports the idea that the planktonic communities in the Mediterranean Sea act as $\mathrm{CO}_{2}$ sources.

Using artificial neural networks, the GPP: $R$ ratio could be modelled in three shallow European bays using sampling depth, DOC and temperature as input variables (RochelleNewall et al., 2007). However, this model did not produce satisfying data for the Bay of Villefranche (C. Winter, personal communication, 2006). One of the reasons could be the greater water depth ( $>90 \mathrm{~m}$ at Point B compared to a maximum depth of $37 \mathrm{~m}$ at the other study sites). In addition, the frequent episodic events encountered during the study could have masked potential relationships between parameters.

\subsection{Co-variation between parameters}

The co-variations between some parameters were significant, however, not very strong. Co-variations between parameters such as between GPP and BP are often more easily detected along trophic gradients than within systems during seasonal studies. A variety of mutually not exclusive factors can be the reasons for such an uncoupling between bacterioplankton and phytoplankton production. First, while BP and GPP are typically well related across systems (e.g. Baines and Pace, 1991; Cole et al., 1988), DOC consumption and BP can show a time lag during seasonal studies (Sherr and Sherr, 1996). This was also observed in our study (Figs. 7 and 9). Second, DOC utilization could be nutrient-limited (Thingstad et al., 1997). This hypothesis was actually developed using data from the Bay of Villefranche. Third, the use of allochthonous DOC could cause this uncoupling (Alonso-Saez et al., 2008). The significance of allochthonous carbon sources remains unknown in the Bay of Villefranche. However, as discussed 
Table 1. Spearman correlation matrix of all parameters for which significant $(P<0.0001)$ and relevant $(\rho>0.5)$ correlation coefficients were found (in italics). The threshold for $P<0.05$ was at $\rho=0.2$. GPP, NCP and $R$ data were not included in this analysis, since they were sampled at a lower frequency. sp. BP, cell-specific bacterial production.

\begin{tabular}{lrrrrrrrrrrr}
\hline Parameters & $T$ & $\mathrm{NO}_{3}$ & $\mathrm{PO}_{4}$ & DOC & Particles & Chl- $a$ & BA & sp. BP & BP & BR & BGE \\
\hline $\mathrm{NO}_{3}$ & -0.582 & & & & & & & & & & \\
$\mathrm{PO}_{4}$ & 0.159 & 0.641 & & & & & & & & & \\
DOC & 0.637 & -0.582 & -0.298 & & & & & & & & \\
Particles & -0.342 & 0.114 & -0.075 & -0.085 & & & & & & & \\
Chl- $a$ & -0.712 & 0.330 & -0.029 & -0.412 & 0.521 & & & & & & \\
BA & -0.401 & 0.46 & -0.124 & -0.043 & 0.465 & 0.505 & & & & & \\
sp. BP & 0.432 & -0.248 & -0.212 & 0.249 & -0.171 & -0.288 & -0.061 & & & & \\
BP & 0.239 & -0.444 & -0.406 & 0.374 & 0.155 & 0.031 & 0.246 & 0.592 & & & \\
BR & 0.189 & -0.061 & -0.069 & -0.206 & -0.036 & -0.131 & -0.076 & 0.375 & 0.263 & & \\
BGE & 0.084 & -0.275 & -0.253 & 0.231 & 0.144 & 0.052 & 0.194 & 0.209 & 0.659 & -0.508 & \\
BCD & 0.284 & -0.099 & -0.118 & -0.267 & -0.078 & -0.167 & -0.040 & 0.501 & 0.292 & 0.978 & -0.490 \\
\hline
\end{tabular}

below, this uncoupling could also be linked to episodic events introducing not only carbon but also nutrients into the system.

\subsection{Seasonal and episodic variation of planktonic metabolism}

In temperate marine ecosystems, the spring phytoplankton bloom is often a period during which changes in biological activity are prominent (e.g. Serret et al., 1999). This was also observed in the present study as bacterial production and respiration showed maxima following the GPP and Chl- $a$ maximum. Elevated Chl- $a$ concentrations were also observed in fall together with a elevated bacterial abundance and respiration. Such fall Chl- $a$ maxima are not only known for the Bay of Villefranche (Bustillos-Guzmán et al., 1995) but also from other bays (e.g. Moncoiffé et al., 2000; Alonso-Saez et al., 2008). Moreover, differences between hydrologically defined periods support the idea that phytoplankton blooms fuel bacterial production (Baines and Pace, 1991), e.g. by release of organic matter or formation of detritus. In this sense, typical seasonal variability was detected. However, we also observed other potential sources of changes occurring on a different time scale and at less predictable frequencies such as heavy rain fall, wind driven upwelling, forest fires and a strong wet deposition event of Sahara dust. Precipitation events can introduce DOC and nutrients into the systems either directly from the atmosphere or indirectly with coastal run-off. Such events could not be clearly related to changes in autotrophic or heterotrophic processes in the present study, e.g. due to co-occurring events such as phytoplankton blooms or because the sampling was not frequent enough. Therefore, specific rain precipitation events are not discussed in the following.

Phosphate concentrations were higher during the summer period than in late spring and early fall. In July, a local wind-driven upwelling event occurred that brought cold and nutrient-rich deep water into the Bay. Upwelling events have been described before for this bay (Nival et al., 1975). In addition, the frequency of forest fires was high during summer 2003 and might have supplied nutrients, since it is well known that fly ash from forest fires contains inorganic nutrients (e.g. phosphorus; Schumann and Summer, 2000). While the upwelling event was a singular event, forest fires were more frequent and long lasting in summer 2003.

As in other studies (Thingstad et al., 1997) we noted in the Bay of Villefranche an increase in DOC concentration following the spring bloom event. This is also supported by the finding that DOC concentration increased significantly with temperature. However, this accumulation phase of DOC ended earlier in 2003 than in previous years (Thingstad et al., 1997), i.e. before the seasonal erosion of the thermocline due to storms (winter mixing), although the strong forest fires should have supplied additional organic carbon in this year (e.g. in the form of black carbon) to the system. The Bay of Villefranche is typically P-limited in summer (Dolan et al., 1995; Thingstad et al., 1998). The phosphorus input by upwelling and forest fires could have relieved this P-limitation and stimulated GPP and BP, however, we found only a stimulation of BP. Synechococcus is a particularly strong competitor for phosphate and among the most abundant phytoplankton in summer (Tanaka et al., 2004). Thus, we hypothesize that the higher supply of phosphate by forest fires could have stimulated heterotrophic bacterial over photosynthetic process and resulted in the enhanced BP:GPP ratio observed in July-August. In addition, it is possible that not only phosphate but also some organic $P$ has been imported by atmospheric deposition originating from forest fires and used by heterotrophic bacteria. The consequence of the upwelling and, particularly, of the atmospheric input could have been the oxidation of the accumulated DOC by relieving the competition for phosphate between bacterio- and phytoplankton 
(Thingstad et al., 1997, 1998). Therefore, it is possible that less carbon was exported due to winter mixing in this year.

A particularly strong Sahara dust deposition event occurred in February 2004 and was associated with heavy rainfall. Sahara dust deposition events are frequently recorded in the NW Mediterranean; but they typically occur as dry deposition (Guerzoni et al., 1992; Ridame and Guieu, 2002). Aerosol deposition of $\mathrm{Fe}$ and $\mathrm{Ca}$ during the February 2004 event was ca. 7- and 3-fold higher than in the previous week, while wet deposition of phosphate and nitrate was 5- and 6fold higher compared to the values usually recorded at that time of the year (C. Migon, personal communication, 2005). In addition, particle load measured a few days after the event was almost 2-fold higher than the month before. Also, nitrate and phosphate concentrations were higher than in the week before. Although rain and Sahara dust can contain phosphorus and organic carbon (Migon and Sandroni, 1999; PulidoVillena et al., 2008; Ridame and Guieu, 2002), we could only detect elevated phosphate but not elevated DOC values after the end of the wet deposition event. Pulido-Villena et al. (2008) calculated phosphate and DOC input from deposition data and data measured in situ in the NW Mediterranean Sea ( $45 \mathrm{~km}$ off the Bay of Villefranche) and estimated that during a dry deposition event in June 2006, $0.01 \mu \mathrm{m}$ phosphate and $2.6 \mu \mathrm{m}$ DOC were added to the mixed water column. Such an import of DOC is likely too small to be detectable against the background values (ca. $60 \mu \mathrm{m}$ in January to February 2004). GPP and Chl- $a$ were not affected by atmospheric depositions when data were compared to the previous sampling date. This suggests that phytoplankton (and bacterioplankton) was not limited by nutrients and this concurs with the idea that nutrients are replenished in February by regeneration and mixing. Thus, the limiting factor for phytoplankton was probably light.

In contrast, bacterial parameters such as abundance, production and growth efficiency increased after the wet deposition event. Bacterial abundance and production were ca. 1.4 and 1.3 times, respectively, higher than at the next sampling for bacterial parameters, when the phytoplankton bloom had already started. This supports other studies, who have demonstrated in an in situ study and in experiments that the DOC input by a dry deposition event can stimulate bacterial growth (Pulido-Villena et al., 2008). In addition, Sahara dust material collected during the deposition event in 2004 contained organic material and stimulated bacterial production in experiments (Lekunberri et al., 2010). The increase in BGE during the Sahara dust wet deposition event (Fig. 6d) suggests that the DOC provided was labile. In addition, adsorption of organic matter in the water to the dust particles along with colonization of particles by bacteria and subsequent use of this concentrated organic material could have caused the increased production. Such an attachment could be the reason, why the lowest bacterial abundance (i.e. freeliving bacteria) were found at the particle peak in $20 \mathrm{~m}$ depth, since attached bacteria are not detected by standard FCM analysis. While the detailed mechanisms remain unknown, our data suggest a stimulation of bacterial production and biomass due to the Sahara dust event. In a experimental study with Sahara dust collected during this event, Lekunberri et al. (2010) found an initial switch to heterotrophy. This suggests that at short-term Sahara dust rather stimulates BP than GPP, e.g. due to DOC input. This increased bacterial activity might also influence the subsequent development of the phytoplankton bloom, e.g. by binding nutrients into bacterial biomass.

\section{Conclusions}

We found seasonal variability of planktonic auto- and heterotrophic processes in an oligotrophic coastal environment. The data also suggest that episodic short-term events such as forest fires and Sahara dust deposition can strongly modify the seasonal variability of phytoplankton and bacterioplankton-mediated ecosystem processes and the trophic balance. As climate modelling suggests that forest fires and Sahara dust events will increase in the future (Anderson et al., 2003; Ramanathan et al., 2007), the detected influence of episodic events could become more important, e.g. in terms of controlling plankton productivity and carbon export and shifting the trophic balance.

Acknowledgements. We thank J.-Y. Carval for skillful assistance during all the field work. C. Heyndrickx for the weekly CTD, nutrient and chlorophyll data and the framework of the SOMLIT program. G. Gorsky and I. Palazzoli are acknowledged for sharing their data on particles. The meteorological station at Cap-Ferrat kindly provided meteorological data. Peter Williams and two anonymous referees provided very useful comments, which improved the manuscript. This research was supported by the European Union in the framework of the projects BASICS (EVK3-CT-2002-00078) and SESAME (No. GOCE-2006-036949) to MGW, EUROTROPH (EVK3-CT-2000-00040) to JPG, the ATIPE grant (CNRS) to MGW and a scholarship from the French Ministry of Education and Research to OBF.

Edited by: K. Suzuki

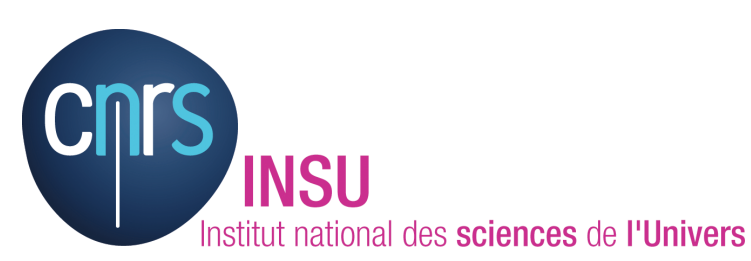

The publication of this article is financed by CNRS-INSU.

\section{References}

Alonso-Saez, L., Vazquez-Dominguez, E., Cardelus, C., Pinhassi, J., Sala, M. M., Lekunberri, I., Balagué, V., Vila-Costa, M., 
Unrein, F., Massana, R., Simo, R., and Gasol, J. M.: Factors controlling the year-round variability in carbon flux through bacteria in a coastal marine system, Ecosystems, 11, 397-409, 2008.

Anderson, L., Haraldson, C., and Roger, L.: Gran linearization of potentiometric Winkler titration, Mar. Chem., 37, 179-190, 1992.

Anderson, T., Charlson, R., Schwartz, S., Knutti, R., Boucher, O., and Rohde, H.: Climate forcing by aerosols - a hazy picture, Science, 300, 1103-1104, 2003.

Azam, F., Fenchel, T., Field, J. G., Gray, J. S., Meyer-Reil, L. A., and Thingstad, T. F.: The ecological role of water-column microbes in the sea, Mar. Ecol. Prog. Ser., 10, 257-263, 1983.

Baines, S. B. and Pace, M. L.: The production of dissolved organic matter by phytoplankton and its importance to bacteria: patterns across marine and freshwater system, Limnol. Oceanogr., 36, 1078-1090, 1991.

Bustillos-Guzmán, J., Claustre, H., and Marty, J.-C.: Specific phytoplankton signatures and their relationship to hydrographic conditions in the coastal NW Mediterranean Sea. Mar. Ecol. Prog. Ser., 124, 247-258, 1995.

Benner, R. and Strom, M.: A critical evaluation of the analytical blank associated with DOC measurements by high-temperature catalytic oxidation, Mar. Chem., 41, 153-160, 1993.

Cattaneo, R., Rouvière, C., Rassoulzadegan, F., and Weinbauer, M. G.: Association of viruses and bacteria with reference black carbon particles in marine coastal waters: A scanning electron, epifluorescence and confocal laser scanning microscopy analysis, FEMS Microbiol. Ecol., 74, 382-396, 2010.

Claustre, H., Marty, J.-C., and Cassiani, L.: Intraspecific differences in the biogeochemical composition of a diatom during a spring bloom in Villefranche-sur-mer Bay, J. Exp. Mar. Biol. Ecol., 129, 17-32, 1989.

Cole, J. J., Findlay, S., and Pace, M. L.: Bacterial production in fresh and saltwater ecosystems: a cross-system overview, Mar. Ecol. Prog. Ser., 43, 1-10, 1988.

Dachs, J., Calleja, M. L., Duarte, C. M., del Vento, S., Turpin, B., Polidori, M., Herndl, G. J., and Agusti, S.: High atmosphereocean exchange of organic carbon in the NE subtropical Atlantic, Geophys. Res. Lett., 32, L21807, doi:10.1029/2005GL023799, 2005.

Del Giorgio, P. A. and Cole, J.: Bacterial growth efficiency in natural aquatic systems, Ann. Rev. Ecol. Syst. 29, 503-541, 1998.

Del Giorgio, P. A., Cole, J., and Cimbleris, A.: Respiration rates in bacteria exceed phytoplankton production in unproductive aquatic systems, Nature, 385, 148-151, 1997.

Del Giorgio, P. A. and Williams, P. L.: Respiration in aquatic ecosystems, Oxford Univ. Press. Inc., Oxford, 2005.

Dolan, J., Thingstad, T. F., and Rassoulzadegan, F.: Phosphate transfer between microbial size-fractions in Villefranche Bay (NW Mediterranean Sea), France in autumn 1992, Ophelia, 41, 71-85, 1995.

Duarte, C. M. and Agusti, S.: The $\mathrm{CO} 2$ balance of unproductive aquatic ecosystems, Science, 281, 234-236, 1998.

Duarte, C. M., Agusti, S., and Vaqué, D.: Controls on planktonic metabolism in the Bay of Blanes, NW Mediterranean littoral, Limnol. Oceanogr., 49, 2162-2170, 2004.

Duarte, C. M. and Cebrian, J.: The fate of marine autotrophic production, Limnol. Oceanogr., 41, 1758-1766, 1996.

Duarte, C. M., Middelburg, J. J., and Caraco, N.: Major role of marine vegetation on the oceanic carbon cycle, Biogeosciences, 2, 1-8, doi:10.5194/bg-2-1-2005, 2005.

Duarte, C. M. and Regaudie-de-Gioux, A.: Thresholds of gross primary production for the metabolic balance of marine planktonic communities, Limnol. Oceanogr., 54, 1015-1022, 2009.

Fuhrman, J. A. and Azam, F.: Thymidine incorporation as a measure of heterotrophic bacterioplankton production in marine surface waters: evaluation and field results, Mar. Biol., 66, 109-120, 1982.

Gasol, J. and Del Giorgio, P. A.: Using flow cytometry for counting natural planktonic bacteria and understanding the structure of planktonic bacterial communities, Sci. Mar., 64, 197-224, 2000.

Gaston, J.: Etude du courant géostrophique entre Villefranche-surmer et Calvi. Cah., Océanogr., 19, 329-345, 1967.

Gazeau, F., Duarte, C. M., Gattuso, J.-P., Barrón, C., Navarro, N., Ruiz, S., Prairie, Y. T., Calleja, M., Delille, B., Frankignoulle, M., and Borges, A. V.: Whole-system metabolism and $\mathrm{CO}_{2}$ fluxes in a Mediterranean Bay dominated by seagrass beds (Palma Bay, NW Mediterranean), Biogeosciences, 2, 43-60, doi:10.5194/bg-2-43-2005, 2005.

Gonzalez, N., Gattuso, J.-P., and Middelburg, J. J.: Oxygen production and carbon fixation in oligotrophic coastal bays and the relationships with gross and net primary production, Aquat. Microb. Ecol., 52, 119-130, 2008.

Guerzoni, S., Landuzzi, W., Lenaz, R., Quarantotto, G., Cesari, G., Rampazzo, R., and Molinaroli, E.: Mineral atmospheric particulate from south to northwest Mediterranean: seasonal variations and characteristics, Water Poll. Res. Reports, 28, 483-493, 1992.

Kirchman, D. L., K'Ness, E., and Hodson, R.: Leucine incorporation and its potential as a measure of protein synthesis by bacteria in natural aquatic systems, Appl. Environ. Microbiol., 49, 599607, 1985.

Kirchman, D. L. and Ducklow, H. W.: Estimating conversion factors for the thymidine and the leucine methods for measuring bacterial production, edited by: Kemp, P. F., Sherr, B. F., Sherr, E. B., and Cole, J. J., Handbook of Methods in Aquatic Microbial Ecology, Lewis Publishers, 513-518, 1993.

Knap, A. H., Michaels, A. E., Close, A., Ducklow, H. W., and Dickson, A. G.: Protocols for the Joint Global Ocean Flux Study (JGOFS) core measurements, JGOFS Report Nr. 19, Bergen, Norway, 1996.

Lee, S. and Fuhrman, J. A.: Relationships between biovolume and biomass of naturally derived marine bacterioplankton, Appl. Environ. Microbiol., 53, 1298-1303, 1987.

Legendre, L. and Le Fèvre, J.: Microbial food webs and the export of biogenic carbon in oceans, Aquat. Microb. Ecol., 9, 69-77, 1995.

Lekunberri, I., Lefort, T., Romero, E., Vázquez-Domínguez, E., Marrasé, C. Peters, F., Weinbauer, M. G., and Gasol., J. M.: Effects of a dust deposition event on coastal marine microbial abundance and activity, bacterial community structure, and ecosystem function, J. Plankton Res., 381-396, 2010.

Lorenzen, C.: A method for the continuous measurement of in vivo chlorophyll concentration, Deep-Sea Res. Pt. I, 13, 223-227, 1966.

Migon, C. and Sandroni, V.: Phosphorus in rainwater: Partitioning inputs and impact on the surface coastal ocean, Limnol. Oceanogr., 44, 1160-1165, 1999.

Morel, A. and André, J. M.: Pigment distribution and primary 
production in the Western Mediterranean as derived and modeled from coastal zone scanner observation, J. Geophys. Res., 86, 12685-12698, 1991.

Moncoiffé, G., Alvarez-Salgado, X. A., Figueiras, F. G., and Savidge, G.: Seasonal and short-term-scale dynamics of microplankton community production and respiration in an inshore upwelling system, Mar. Ecol. Porg. Sr., 196, 111-126, 2000.

Navarro, N., Agusti, S., and Duarte, C. M.: Plankton metabolism and dissolved organic carbon use in the Bay of Palma, NW Mediterranean Sea, Aquat. Microb. Ecol., 37, 47-54, 2004.

Nival, P. and Corre, M. C.: Variation annuelle des charactéristiques hydrologiques de surface dans la rade de Villefranche-sur-mer, Ann. Inst. Océanogr. Paris, 52, 57-78, 1976.

Nival, P., Malara, G., and Charra, R.: Evolution du plankton de la baie de Villefranche-sur-Mer à la fin du printemps (mai et juin 1971). I. Hydrologie, sels nutritifs, chlorophylle, Vie et Milieu, 25, 231-260, 1975 .

Pulido-Villena, E., Wagener, T., and Guieu, C.: Bacterial response to dust pulses in the western Mediterranean: Implications for carbon cycling in the oligotrophic ocean, Global Biogeochem. Сy., 22, GB1020, doi:10.1029/2007GB003091, 2008.

Ramanathan, V., Ramana, M. V., Roberts, G., Kim, D., Corrigan, C., Chung, C., and Winker, D.: Warming trends in Asia amplified by brown cloud solar absorption, Nature, 448, 575-578, 2007.

Regaudie-de-Gioux, A., Vaquer-Sunyer, R., and Duarte, C. M.: Patterns in planktonic metabolism in the Mediterranean Sea, Biogeosciences, 6, 3081-3089, doi:10.5194/bg-6-3081-2009, 2009.

Ridame, C. and Guieu, C. Saharan input of phosphate to the oligotrophic water of the open Western Mediterranean Sea, Limnol. Oceanogr., 47, 856-869, 2002.

Robinson, C., Serret, P., Tilstone, G., Teira, E., Zubkov, M. V., Rees, A. P. and Woodward, M. S.: Plankton respiration in the eastern Atlantic Ocean, Deep Sea Res. Pt. I, 49, 787-813, 2002.

Rochelle-Newall, E., Winter, C., Barron, C., Borges, A. V., Duarte, C. M., Elliott, M., Frankignoulle, M., Gazeau, F., Middelburg, J. J., Pizay, M.-D., and Gattuso, J.-P.: Artificial neural network analysis of factors controlling ecosystem metabolism in coastal systems, Ecol. Appl., 17, S185-S196, 2007.

Satta, M., Agusti, S., Mura, M., Vaqué, D., and Duarte, C. M.: Microplankton respiration and net community metabolism in a bay on the NW Mediterranean coast, Aquat. Microb. Ecol., 10, 165-172, 1996.

Schumann, A. W. and Sumner, M. E.: Chemical evaluation of nutrient supply from fly ash - biosolids mixtures, Soil Sci. Soc. Am. J., 64, 419-426, 2000.

Serret, P., Fernández, E., Sostres, J. A., and Anadón, R.: Seasonal compensation of microbial production and respiration in a temperate sea, Mar. Ecol. Prog. Ser., 187, 43-57, 1999.
Serret, P., Robinson, C., Fernandez, E., Teira, E., and Tilstone, G.: Latitudinal variation of the balance between plankton photosynthesis and respiration in the eastern Atlantic Ocean, Limnol. Oceanogr., 46, 1642-1652, 2001.

Sheldon, R. W., Rassoulzadegan, F., Azam, F., Berman, T., Bezanson, D. S., Bianchi, M., Bonin, D., Hagström, Å., Laval-Peuto, M., Neveux, J., Raimbault, P., Rivier, A., Sherr, B., Sherr, E., Van Wambeke, F., Wikner, J., Wood, A. M., and Yentsch, C. M.: Nano- and picoplankton growth and production in the Bay of Villefranche sur Mer (N. W. Mediterranean), Hydrobiologia, 241, 91-106, 1992.

Sheldon, R. and Parsons, T.: A continuous size spectrum for particulate matter in the sea, J. Fish Res. Bd. Canada, 24, 909-915, 1967.

Sherr, E. B. and Sherr, B. F.: Temporal offset in oceanic production and respiration processes implied by seasonal changes in atmospheric oxygen, Aquat. Microb. Ecol., 11, 91-100, 1996.

Smith, D. C. and Azam, F.: A simple, economical method for measuring bacterial protein synthesis rates in seawater using ${ }^{3} \mathrm{H}-$ leucine, Mar. Microb. Food Webs, 6, 107-114, 1992.

Smith, E. and Kemp, W.: Size structure and the production/respiration balance in a coastal plankton community, Limnol. Oceanogr. 46, 473-485, 2001.

Strickland, J. D. H. and Parsons, T. R.: A practical handbook of seawater analysis, Bull. 167 Fish. Res. Bd., Canada, 1972.

Tanaka, T., Rassoulzadegan, F., and Thingstad, T. F.: Orthophosphate uptake by heterotrophic bacteria, cyanobacteria, and autotrophic nanoflagellates in Villefranche Bay, northwestern Mediterranean: Vertical, seasonal, and short-term variations of the competitive relationship for phosphorus, Limnol. Oceanogr., 49, 1063-1072, 2004.

Thingstad, T. F., Hagström, A., and Rassoulzadegan, F.: Accumulation of degradable DOC in surface waters: Is it caused by a malfunctioning microbial loop?, Limnol. Oceanogr., 42, 398-404, 1997.

Thingstad, T. F., Zweifel, U. L., and Rassoulzadegan, F.: P limitation of heterotrophic bacteria and phytoplankton in the northwestern Mediterranean, Limnol. Oceanogr., 43, 88-94, 1998.

Williams, P. L.: The balance of plankton respiration and photosynthesis in the open ocean, Nature, 394, 55-57, 1998.

Williams, P. L. and Bowers, D.: Regional carbon imbalances in the ocean, Science, 284, 173-174, 1999.

Williams, P. L., Morris, P., and Karl, D. M.: Net community production and metabolic balance at the oligotrophic ocean site, station ALOHA, Deep Sea Res. Pt. I, 51, 1563-1578, 2004.

Zhang, R., Weinbauer, M. G., and Qian, P.-Y.: Viruses and flagellates sustain apparent richness and reduce biomass accumulation of bacterioplankton in coastal marine waters, Environ. Microbiol., 9, 2008-2018, 2007. 